\title{
STUDI PEMBELAJARAN DRAMA DI SMA KOTA BENGKULU
}

\author{
Egi Nusivera \\ eghie_nusivera06@yahoo.com \\ Dosen pada Prodi Pendidikan Bahasa dan Sastra Indonesia, UHAMKA Jakarta
}

\begin{abstract}
Abstrak
Penelitian ini bertujuan untuk mengetahui dan mendeskripsikan data mengenai perencanaan dan proses pembelajaran drama di Sekolah Menengah Atas (SMA) di Kota Bengkulu. Jenis penelitian ini adalah penelitian survey dengan menggunakan metode deskriptif. Penelitian ini dilakukan di kelas XI yang terdapat pada tiga sekolah yaitu pada SMA N 5, SMA N 6, dan SMA N 8 Kota Bengkulu. Teknik pengumpulan data dilakukan dengan menggunakan teknik observasi dan wawancara. Teknik analisis data dalam penelitian ini dilakukan dengan tiga siklus yaitu, reduksi data, penyajian data, dan verifikasi data atau penarikan kesimpulan terhadap data yang telah diambil. Hasil penelitian ini menunjukkan bahwa perencanaan yang matang diperlukan agar pembelajaran berjalan efektif. Perencanaan pembelajaran tersebut dapat dibagi menjadi perencanaan Silabus dan RPP, perencanaan media pembelajaran drama, serta perencanaan siswa sebelum pembelajaran berlangsung. Sedangkan pada proses pembelajaran, proses pembelajaran yang ada pada SMA N 5 tergolong berhasil, sedangkan pada SMA N 6 dan SMA 8 proses pembelajaran yang dilakukan tidak sesuai dengan perencanaan pembelajaran yang sebelumnya telah di persiapkan.
\end{abstract}

Kata Kunci: pembelajaran, drama, SMA, Kota Bengkulu.

\section{PENDAHULUAN}

Sesuai dengan isi kurikulum, pembelajaran bahasa memiliki empat keterampilan berbahasa, empat kompetensi itu meliputi keterampilan mendengar, berbicara, membaca, dan menulis. Karris dalam Tarigan (1977:9) menyatakan bahwa bahasa mempunyai empat komponen yaitu keterampilan membaca (reading skills), keterampilan menulis (writing skills), keterampilan berbicara (speaking skills), keterampilan menyimak (listening skills). Apabila keempat keterampilan tersebut dikaitkan dalam proses pembelajaran, maka pembelajaran akan lebih terfokus.

Dalam kegiatan pembelajaran sastra misalnya, jika empat kompetensi tersebut dihubungkan maka secara bertahap siswa memiliki kemampuan untuk mengapresiasikan sastra. Salah satu bentuk karya sastra itu adalah drama. Berbeda dengan karya satra yang lain, drama ditulis bukan untuk dibaca saja, tetapi untuk dipertunjukkan. Drama juga merupakan seni yang melakonkan kehidupan dimasyarakat. Dari drama kita bisa melihat budaya yang ada pada sebuah masyarakat. Drama merupakan sebuah karya sastra yang mempunyai dua dimensi karakter (Hasanudin, 2009: 3). Terlebih lagi Hasanudin (2009: 6) menyatakan bahwa drama penuh irama dan karya akan bunyi yang indah, namun sekaligus menggambarkan watak-watak manusia secara tajam, serta menampilkan peristiwa yang penuh dengan kesuspenan.

Pendalaman dan pemahaman tujuan tersebut ikut menentukan baik tidaknya pengajaran drama di sekolah. Namun, pada kenyataannya pengajaran sastra tidaklah seindah yang dibayangkan, karena banyaknya tenaga 
pengajar yang tidak mampu untuk mengajarkan sastra dan dengan berlandaskan atas dasar ketidaktersediaan media ataupun sarana serta metode untuk pengajaran sastra, sehingga harapan terhadap keberhasilan pengajaran sastra sulit untuk terpenuhi. Hal ini perlu mendapatkan perhatian khusus sebab dapat mengganggu proses pengajaran sastra, khususnya di Sekolah Menengah Atas, sedangkan pembelajaran sastra pada umumnya dan pembelajaran drama pada khususnya mengemban misi efektif yaitu memperkaya pengalaman dan meningkatkan kemampuan berbicara dan mendengar bagi siswa. Berdasarkan latar belakang di atas, peneliti perlu melakukan penelitian lebih lanjut untuk mengkaji lebih lanjut mengenai "Studi Pembelajaran Drama di SMA Kota Bengkulu".

Fokus masalah penelitian ini adalah rencana proses pembelajaran (RPP) drama dan proses pembelajaran drama yang dilakukan di Sekolah Menengah Atas di Kota Bengkulu.

Berdasarkan batasan masalah, maka penulis merumuskan permasalahan yaitu: (1) Bagaimanakah rencana proses pembelajaran (RPP) drama pada Sekolah Menengah Atas (SMA) Kota Bengkulu? (2) Bagaimanakah proses pelaksanaan pembelajaran drama yang dilakukan di Sekolah Menengah Atas di Kota Bengkulu?. Tujuan penelitian ini untuk mengetahui dan mendeskripsikan data mengenai perencanaan dan proses pembelajaran drama di Sekolah Menengah Atas (SMA) di Kota Bengkulu.

Manfaat dari penelitian ini adalah secara teoritis, dapat memberikan informasi tentang perencanaan pembelajaran dan proses pembelajaran drama pada siswa SMA di Kota Bengkulu secara nyata. Secara praktis, hasil penelitian ini akan memberikan sumbangan yang bermanfaat pada guru, siswa dan peneliti sendiri dalam rangka perbaikan pembelajaran Bahasa Indonesia khususnya pada pembelajaran drama.

Dalam bukunya Sugandi, dkk. (2004: 9) menyatakan bahwa pembelajaran terjemahan dari kata "instruction" yang berarti self instruction (dari internal) dan instructions (dari eksternal). Pembelajaran yang bersifat eksternal antara lain datang dari guru yang disebut pengajaran. Dalam pembelajaran yang bersifat eksternal prinsip-prinsip belajar dengan sendirinya akan menjadi prinsip-prinsip pembelajaran. Sejalan dengan pedapat Sugandi, Ahmad, dkk. Mulyansa (2003: 100) dalam Rohmadi dan Subiyantoro (2011: 65) menyatakan bahwa pembelajaran adalah proses interaksi antara siswa dengan lingkungannya, sehingga terjadi perubahan perilaku kearah yang lebih baik.

Hamalik (2001: 57) dalam Rohmadi dan Subiyantoro (2011: 65) juga menyatakan bahwa pembelajaran merupakan kombinasi antara unsurunsur manisiawi, material, fasilitas, perlengkapan, dan prosedur yang saling mempengaruhi untuk mencapai tujuan pembelajaran.

Tujuan pembelajaran dalam bukunya Sugandi, dkk. (2000: 25) adalah membantu siswa pada siswa agar memperoleh berbagai pengalaman dan dengan pengalaman itu tingkah laku yang dimaksud meliputi pengetahuan, keterampilan, dan nilai atau norma yang berfungsi sebagai pengendali sikap dan 
prilaku siswa. Tujuan pembelajaran menggambarkan kemampuan atau tingkat penguasaan yang diharapkan dicapai oleh siswa setelah mereka mengikuti suatu proses pembelajaran.

Drama berasal dari bahasa Yunani "Draomai" yang berarti berbuat, berlaku, bertindak atau beraksi. Drama berarti perbuatan, tindakan, beraksi, atau action (Waluyo, 2001: 2). Dalam drama, penulis ingin menyampaikan pesan melalui akting dan dialog. Biasanya drama menampilkan sesuatu hal yang biasa terjadi dalam kehidupan kita sehari-hari. Sehingga para penonton diajak untuk seolah-olah ikut menyaksikan dan merasakan kehidupan dan kejadian dalam masyarakat. Brahim (1968: 51-52) menyatakan drama merupakan pertunjukan dan adanya lakon yang dibawakan dalam pertunjukan itu. Sedangkan Ferdinand Brunetiere dan Balthazar Verhagen dalam (Hasanudin, 2002: 2) menyatakan drama adalah kesenian yang melukiskan sifat dan sikap manusia dan harus melahirkan kendak manusia dengan action dan prilaku.

Sebagai sebuah karya seni, drama diterima oleh pembaca dan penontonnya sebagai suatu suguhan gambaran yang penuh peristiwa, penuh watak, dan penuh persoalan. Namun bentuk yang utuh dan menyatu tadi sebenarnya dapat dianalisis dalam unsurunsurnya. Sumardjo (1984: 127) menyatakan drama dimasukkan sebagai karya sastra karena ditulis dalam bahasa yang memikat dan mengesankan. Terlebih lagi Jakob Sumardjo mengatakan kebanyakan drama dunia (kalsik) justru ditulis dalam bentuk sajak, penuh irama dan kaya akan bunyi yang indah, namun sekaligus juga menunjukkan watak-watak manusia secara tajam, dan menunjukkan peristiwa yang mendebarkan.

Endaswara (2011: 149) menyatakan, secara umum dapat dikatakan bahwa pembelajaran mengapresiasikan drama selalu bermula dengan pembelajaran membaca naskah. Naskah menjadi tumpuan apresiasi drama. Untuk mengerti dan dapat memahami naskah drama tersebut, kita terlebih dahulu harus memahami materimateri yang ada didalam drama. Unsur pembentuknya dan pengertian dari drama itu sendiri. Drama adalah karya sastra yang menggambarkan aktivitas kehidupan manusia yang dalam penceritaannya menekankan dialog, laku, dan gerak. Meski drama adalah karya sastra yang bisa dibaca dan dianalisa secara tekstual karena menggunakan medium bahasa dalam penciptaannya, namun drama pada dasarnya ditulis untuk dipentaskan di atas panggung (stage). Oleh karena itu, dalam teks drama, selain terdapat unsur dialog sebagai penanda alur cerita, pembaca juga akan menemukan gambaran ekspresi dan laku (stage direction) yang ditulis pengarang untuk memberikan gambaran kepada para pembaca, calon aktor, dan juga sutradara tentang tingkah laku, ekspresi, gerak dan juga mimik tokoh-tokoh dalam drama.

Endaswara (2011: 152) menyatakan bahwa inti dari pembelajaran drama ada dua hal yaitu: (a) apresiasi mulai dari pengenalan, pemahaman, penghayatan, sampai produksi drama, dan (b) pementasan, yaitu berlatih bermain sampai kelak juga diapresiasikan secara terus menerus. 


\section{METODE PENELITIAN}

Jenis penelitian yang akan dilaksanakan dalam penelitian ini adalah penelitian survei dengan menggunakan metode deskriptif. Jenis penelitian survei ini, merupakan penelitian yang mengumpulkan informasi tentang karakteristik, tindakan, pendapat dari sekelompok responden yang representatif yang dianggap sebagai populasi. Tempat penelitian ini dilakukan di kelas XI SMA Negeri 5 Kota Bengkulu, SMA Negeri 6 Kota Bengkulu, dan SMA Negeri 8 Kota Bengkulu. Penelitian ini dilakukan saat jam tatap muka pembelajaran Bahasa Indonesia pada semester ganjil di kelas XI SMA Negeri 5 Kota Bengkulu, SMA Negeri 6 Kota Bengkulu, dan SMA Negeri 8 Kota Bengkulu.

Dalam penelitian ini, data yang diambil berupa data dari guru, dan siswa Sekolah Menengah Atas Kota Bengkulu tahun pelajaran 2012/2013. Sumber data dalam penelitian ini dipilih secara acak, sekolah- sekolah tersebut meliputi SMA Negeri 5 Kota Bengkulu, SMA Negeri 6 Kota Bengkulu, dan SMA Negeri 8 Kota Bengkulu. Teknik pengumpulan data dalam penelitian ini dilakukan melalui observasi, wawancara langsung, dan dokumentasi. Sedangkan teknik analisis data dilakukan dengan menggunakan reduksi data, penyajian data, dan penarikan kesimpulan.

\section{HASIL DAN PEMBAHASAN}

Penelitian ini dilakukan pada tiga sekolah sampel. Sekolah sampel tersebut dipilih melalui pengklasifikasian asumsi masyarakat yang memenilai sekolah tersebut favorit, menengah, dan tarafnya lebih rendah yang dipilih secara acak. Sekolah tersebut terdiri dari SMA N 5,
SMA N 6, dan SMA N 8 Kota Bengkulu. Guru Kelas yang dijadikan sampel sebanyak 3 orang yang terdiri dari 2 guru kelas XI IPA, dan 1 guru kelas XI IPS.

Dari tiga sekolah yang diteliti, yaitu SMA N 5 Kota Bengkulu, SMA N 6 Kota Bengkulu, SMA N 8 Kota Bengkulu, sekolah pertama yang diteliti oleh peneliti adalah SMA N 5 Kota Bengkulu. Penelitian ini dilakukan pada hari Jumat, tanggal 8 September 2012 di kelas XI IPA 4 dengan guru mata pelajaran yang bernama Erna Wilis, S.Pd., dan dibantu oleh Ibu Resi Novalia. Sekolah ke dua yang diteliti adalah SMA Negeri 6, dalam penelitian ini kelas yang diteliti adalah kelas XI IPA 2 yang diampuh oleh Bapak Jon Kenedi, S.Pd.

Sekolah ketiga yang diteliti adalah SMA N 8 Kota Bengkulu Penelitian dilakukan pada hari Senin, tanggal 4 September 2012. Di pegang oleh guru matapelajaran Bahasa Indonesia yang bernama Lisnawati, S.Pd. Di semua sekolah tersebut dari observasi awal diketahui bahwa pembelajaran Bahasa Indonesia dalam satu minggu adalah $2 \mathrm{X}$ jam pelajaran. Setiap satu kali pertemuan waktu belajar adalah 2 jam pelajaran. Satu jam pelajaran terbagi dalam 45 menit. Mata pelajaran Bahasa Indonesia di SMA N 5 Kota Bengkulu diajarkan pada hari Senin pada jam terakhir dan hari Jumat pada jam pertama, pada SMA Negeri 6 Kota Bengkulu pelajaran Bahasa Indonesia diajarkan pada hari Rabu jam pertama dan dan Jumat ketiga dan keempat. Sedangkan di SMA N 8 Kota Bengkulu pelajaran Bahasa Indonesia di dilaksanakan pada hari Selasa jam 3 dan 4 sedangkan Kamis jam terakhir.

Hasil pendataan terhadap persiapan pembelajaran diamati 
menggunakan APKG I yang berkaitan dengan Rencana Proses Pembelajaran (RPP) yang dibuat guru sebelum pembelajaran berlangsung.

Pada RPP yang telah digunakan aspek pembelajaran yang dibuat adalah aspek mendengarkan, dengan standar kompetensi memahami pementasan drama, dan kompetensi dasar mengidentifikasi peristiwa, pelaku, dan perwatakannya, dialog dan konflik pada pementasan drama. Dari penggunaan bahan pelajaran telah sesuai dengan kurikulum yang telah dibuat. Sedangkan pada perumusan tujuannya dilihat pada SMA N 5 tujuan dirumuskan secara khusus, tujuan dibuat berdasarkan aspek kognitifnya saja yaitu siswa mampu mengidentifikasi peristiwa, pelaku, dan perwatakan serta dialog dan konflik pada pementasan drama. Sedangkan pada SMA N 6 dan SMA N 8 karena RPP pada tujuan pembelajarannya, tujuan yang dibuat dipilah berdasarkan aspek kognitif, psikomotor, dan afektifnya. Pada aspek kognitifnya dibuat berdasarkan proses dan pembelajaran dan produk yang nantinya didapat. Pada tahap afektif, tujuan dibuat untuk melihat karekter siswa pada saat pembelajaran, dan keterampilan sosial yang nantinya akan muncul pada saat proses pembelajaran berlangsung.

$$
\text { Pengorganisasian materi }
$$

pembelajaran pada SMA N 5 cukup baik, di dalam RPP materi yang akan diberikan dibuat berdasarkan poin- poin yang nantinya akan diajarkan. Sedangkan pada SMA N 8 dan SMA N 6 materi yang akan diberikan pada saat proses pembelajaran dijabarkan pada RPP yang ada. Materi yang diberikan tersebut meliputi pengertian drama, dialog dalam drama, dan alat apa saja yang digunakan pada saat pementasan drama berlangsung. Materi yang diberikan sesuai dengan kemampuan yang dimiliki oleh siswa.

Pada RPP yang digunakan di SMA N 5 pilihan jenis kegiatan sudah cukup baik, kegiatan meliputi menyampaikan dialog disertai gerak-gerik dan mimik, sesuai dengan watak tokoh. Jenis kegiatan tersebut sudah menjurus pada standar kompetensi memahami pementasan drama. Selain itu juga dalam strategi pembelajaran tersebut RPP yang dibuat meliputi kegiatan tatap muka, terstruktur, dan mandiri. Jadi kegiatan tersebut di buat secara terstruktur dan bertahap. Sedangkan pada SMA N 6 dan SMA N 8 dari RPP yang ada tidak tampak stategi pembelajarannya. Pada SMA N 5 bentuk penilaian yang dilakukan didalam RPP adalah penilaian tes tertulis, tes lisan, penilaian dari observasi kinerja dan demonstrasi, produk, pengukuran sikap, dan penilaian diri. Pada SMA N 6 dan SMA N 8 penilaian dilakukan pada bagian kognitif dan psikolotor, serta penilaian terhadap pengamatan perilaku berkarakter.

Pada proses pembelajaran ini SMA N 5 menggunakan kegiatan pembelajaran yang sesuai dengan tujuan, siswa, materi, situasi, dan lingkungan yang ada. Pada awal pembelajaran, guru melakukan apersepsi tentang drama. Hal pertama yang dilakukan oleh guru adalah bertanya siapa di antaranya yang menyukai film atau drama, drama apa yang mereka suka. Dari pertanyaan tersebut disepakatilah drama Residen Evil yang mereka ketahui, dari judul drama tersebut sang guru menanyakan apa intisari dari drama tersebut. Dalam tahap tersebut sudah tampak keaktifan dan 
antusias dari siswa menjawab pertanyaan, pertanyaan yang diajukan yang bertujuan untuk melihat sejauh mana siswa mengetahui drama tersebut. Setelah bertanya tentang drama Residen Evil yang mereka ketahui, barulah guru mencoba melanjutkannya dengan bertanya tentang apa pengertian dari drama itu sendiri. Setelah beberapa siswa telah memberikan tanggapan barulah sang guru menjelaskan materi tentang drama itu sendiri.

Pada SMA N 6 Kota Bengkulu ini juga diberikan apersepsi tentang materi drama yang bertujuan untuk mengetahui pengetahuan awal siswa. Setelah materi diajarkan, guru memberikan video drama dan menjawab pertanyaan yang diajukan oleh guru. Menurut guru, dengan menggunakan metode ini siswa lebih paham tentang materi yang diajarkan unsur-unsur instrinsik yang telah diberikan. Pada pertemuan selanjutnya guru memberikan tugas untuk membuat naskah drama, dan siswa mementaskannya didepan kelas.

Pada SMA N 8 kegiatan pembelajaran yang dilakukan langsung saja pada pemberian materi drama. Tidak terlihat guru melakukan apersepsi untuk mengetahui pengetahuan awal siswa tentang materi drama. Dalam proses pembelajaran, guru langsung pada pemberian materi yang menjurus pada tujuan pembelajaran. Kegiatan pembelajaran yang dilakukan sesuai dengan perkembangan dan kebutuhan siswa sehingga terdapat kemungkinan besar siswa mengerti atau paham terhadap apa yang telah dipelajari. Akan tetapi, terdapat siswa yang kurang mengerti dan paham materi drama yang telah diajarkan. Hal itu diakibatkan oleh tidak terdapatnya motivasi belajar dari siswa itu sendiri. Padahal guru telah memberikan materi pelajaran sesuai dengan lingkungan belajar.

Ibrahim dan Nana Syaodih (2010:55) menyatakan bahwa proses pengajaran meliputi tiga langkah yaitu langkah perencanaan, pelaksanaan dan evaluasi program pembelajaran. Dari hasil penelitian diatas dapat dilihat bahwa pada persiapan pembelajaran, guru SMA N 5, SMA N 6, dan SMA N 8 terdapat perencanaan RPP dan sialabus sebagai panduan pembelajaran, dan pada dasarnya perencanaan pembelajaran merupakan langkah yang sangat penting sebelum pelaksanaan pembelajaran.

Dari hasil penelitian yang didapat, pada tiga sekolah yang diteliti SMA N 5 keberhasilan guru dalam pembelajaran tercapai. Dilihat dari proses pembelajaran, suasana kelas terkendali, tanggung jawab dari siswa pada saat proses pembelajaran seiring dengan tujuan yang ada pada RPP. Sedangkan pada SMA N 6 dan SMA N 8 proses pembelajaran yang dilaksanakan oleh guru sudah tercapai, akan tetapi perlu pendalaman dan siswa perlu memiliki motivasi lagi agar materi yang diberikan akan mudah dipahami.

Hal ini karena menurut Suwardi Endaswara (2011: 152) inti dari pembelajaran drama ada dua hal yaitu apresiasi mulai dari pengenalan, pemahaman, penghayatan, sampai produksi drama dan hal yang kedua adalah pementasan. Jadi, jika dalam apresiasi pemahaman siswa tidak paham maka pembelajaran drama menjadi siasia. Untuk dapat menyampaikan materi pembelajaran drama dengan baik diperlukan tenaga pengajar yang benarbenar mampu dan menguasai seluk- 
beluk drama, baik secara teori maupun praktik. Lebih jelas lagi Endaswara (2011: 161) menjelaskan bahwa diperlukan belajar yang cukup lama baik bagi para siswa untuk dapat memahami tiap- tiap perbedaan bentuk dan gaya dalam drama. Penguasaan teori dan praktik secara bersama sangat penting agar nantinya para siswa mampu menerapkan teori yang diperolehnya pada saat proses belajar mengajar berlangsung, ke dalam bentuk praktik pementasan naskah drama. Untuk dapat menghasilkan hasil pementasan yang bermutu, tentu saja diperlukan keterlibatan bimbingan tenaga pengajar yang kompeten.

\section{SIMPULAN}

Simpulan yang didapat dalam penelitian ini adalah: (1) Rencana proses pembelajaran yang matang diperlukan supaya pelaksanaan pembelajaran berjalan secara efektif. Dari tiga sekolah yang diteliti, terdapat sekolah yang rencana pembelajarannya belum sesuai dengan kondisi sekolah, kondisi sekitar, kondisi siswa serta kondisi guru yang ada pada sekolah tersebut. (2) Pelaksanaan pembelajaran yang berlangsung di tiga sekolah yang telah diteliti, terdapat sekolah yang pelaksanaan pembelajarannya belum tercapai karena pelaksanaan pembelajaran yang dilakukan tidak sesuai dengan rencana proses pembelajaran yang telah dibuat.

Beberapa saran yang terkait dari hasil penelitian ini diantaranya: (1) Bagi guru diharapkan membuat perencanaan pembelajaran sesuai dengan kondisi sekolah, kondisi siswa, dan kondisi guru itu sendiri. (2) Bagi siswa sebaiknya memiliki motivasi belajar dan perhatian terhadap materi yang diberikan agar mendapatkan pengalaman baru dari hasil pelaksanaan pembelajaran yang telah dilakukan.

\section{Daftar Pustaka}

Arikunto, Suhasimi. 2006. Prosedur Penelitian Suatu Pendekatan Praktik. Jakarta: Rienika Cipta.

Arikunto, Suhasimi. 2006. Prosedur Penelitian Suatu Pendekatan Praktik. Jakarta:Rienika Cipta.

Brahim. 1968. Drama Dalam Pendidikan. Jakarta: Gunung Agung.

Djamarah, Syaiful Bahri dan Aswan Zain. 2010. Strategi Belajar Mengajar (Edisi Revisi). Jakarta: Rineka Cipta

Endaswara, Suwardi. 2011. Metode Pembelajaran Drama (Apresiasi, Ekspresi, dan Pengkajian). Yogyakarta: Caps.

Furchan, Arif. Pengantar Penelitian Dalam Pendidikan. Surabaya: Usaha Nasional Offset Printing

Ganda, Yahya. 1990. Pendidikan Seni Teater Buku Guru Sekolah Menengah Pertama. Jakarta: Rosda Jayaputra.

Hasanuddin, WS. 2009. Drama Karya Dalam Dua Dimensi. Bandung: Angkasa.

Ibrahim, Nana Syaodih. 2010. Perencanaan Pengajaran. Jakarta: PT. Rineka Cipta.

Kaswanti Purwo, Bambang, dkk. 1992. Berbagai Pendekatan dalam Pengajaran Bahasa dan Sastra. Jakarta: Pustaka Sinar Harapan. 
Nurgiyantoro, Burhan. 2009. Teori Pengkajian Fiksi. Yogyakarta: Gadjah Mada University Press.

Rendra, WS. 2007. Seni Drama Untuk Remaja. Jakarta: Burung Merak Press.

Rohmadi, Muhammad, dan Slamet Subianto. 2011. Bunga Rampai Model- Model Pembelajaran Bahasa,Sastra, dam Seni. Surakarta: Yuma Pustaka.

Saptaria, El Rikrik. 2006. Acting Handbook "Panduan Praktis Akting Untuk Film dan Teater. Bandung: Rekayasa Sains.

Singarimbun, Masri, dan Sofian Efendi. 1985. Metode Penelitian Survei. Jakarta: LP3ES

Sitorus, D. Eka. 2003. The Art Of Acting "Seni Peran Untuk Teater, Film, dan TV. Jakarta: PT. Gramedia Pustaka Utama.
Sugandi, Achmad, dkk. 2000. Belajar dan Pembelajaran. Semarang: IKIP Press.

Sugandi, Achmad, dkk. 2004. Teori Pembelajaran. UNESS: UPT MKK.

Sugiyono. 2008. Metode Penelitian Kuantitatif Kualitatif dan R\&D. Bandung: Alfabeta.

Sukmadinata, Nana Syaodih. 2008. Metode Penelitian Pendidikan.

Sumardjo, Jakob. 1984. Memahami Kesusastraan. Bandung: Penerbit Alumni.

Tarigan, Henry Guntur , dan Djargo Tarigan. $\quad 1987 . \quad$ Teknik Keterampilan Berbahasa. Bandung: Angkasa.

Waluyo, Herman J. 2001. Drama "Teori Pembelajarannya". Yogyakarta: PT. Hanindita Graha Widya Yogyakarta. 